\title{
Review: Umbilical Cord Stem Cells
}

\author{
Joseph Ignatius Azzopardi, Renald Blundell \\ Department of Physiology and Biochemistry, University of Malta, Msida, Malta \\ Email: renald.blundell@um.edu.mt
}

How to cite this paper: Azzopardi, J.I. and Blundell, R. (2018) Review: Umbilical Cord Stem Cells. Stem Cell Discovery, 8, 1-11. https://doi.org/10.4236/scd.2018.81001

Received: January 1, 2018

Accepted: January 27, 2018

Published: January 30, 2018

Copyright $\odot 2018$ by authors and Scientific Research Publishing Inc. This work is licensed under the Creative Commons Attribution International License (CC BY 4.0).

http://creativecommons.org/licenses/by/4.0/

\begin{abstract}
The use of umbilical cord blood as an alternative to bone marrow as a source of haematopoietic stem cells for the treatment of certain diseases has been on an increase since the first transplantation of umbilical cord-derived stem cells in 1988. In this paper, 6 of the latest case studies about the use of such stem cells have been discussed and are used as evidence to confirm the potential use of the umbilical cord as a source of haematopoietic stem cells for transplantation as treatment to various diseases. The debate over whether umbilical cord blood should be stored and why public banking facilities are preferred over those that are private have also been discussed in this paper.
\end{abstract}

\section{Keywords}

Umbilical Cord, Haematopoietic Stem Cells, Mesenchymal Stem Cells, Stem Cell Banking

\section{Introduction}

Stem cells are a type of cells which have the ability to self-renew and undergo lineage differentiation [1]. The ability of stem cells to give rise to one or more differentiated cell types is known as developmental plasticity [2]. In the human body, there are three main sources of stem cells: embryonic, adult (or mature) and umbilical cells [3] [4].

The umbilical cord develops from the yolk sac and allantois, becoming the interface between the developing fetus and the placenta allowing blood flow between fetal and maternal circulation. The umbilical cord is composed of two arteries and a vein, surrounded by Wharton's jelly-a gelatinous substance composed of sulphated proteoglycans and a variety of collagenous fibers while lacking in elastic fibers, capillaries and lymphatics. Due to the resistance of the Wharton's jelly against twisting and compression, it functions a protective role to the blood vessels-preventing them from clumping and providing flexibility 
to the cord. The cord is then covered by a simple epithelial layer derived from the amniotic membrane epithelium [5] [6].

At birth, the umbilical cord extends between $30-65 \mathrm{~cm}$ in length, has a mean diameter of $1.5 \mathrm{~cm}$ and weighs circa 40 grams [5].

Once considered a waste product, the umbilical cord, was found to be a source of hematopoietic stem and progenitor cells in 1974 [7]. Apart from hematopoietic stem cells (HSCs), mesenchymal stem cells (MSCs) have also been isolated from the umbilical cord blood by various scientists [8]-[13], although some studies have failed to show their presence in appreciable amounts [14] [15] [16].

\subsection{Advantages of Using Umbilical Stem Cells}

As a source of haematopoietic stem cells for transplantation, there are several advantages of using umbilical cord blood stem cells over bone marrow stem cells, another major source of haematopoietic stem cells [17]. Amongst these advantages, there is the fact that umbilical cord blood contains more stem cells per unit of volume than bone marrow. Umbilical cord stem cells are also more tolerant of Human Leukocyte Antigen (HLA) mismatches than those derived from the bone marrow, leading to a lower rate of graft-versus-host disease being observed when umbilical cord stem cells are used for transplantation [18].

Another major advantage in using umbilical cord stem cells over bone marrow is the ease of collection. Their collection process is not painful to neither the mother nor the child and can be carried out either before or after placental expulsion [19] [20] [21]. An average of $120 \mathrm{~mL}$ of blood can be collected with no risk to either the mother or the baby [22]. On the other hand, collection of bone marrow stem cell requires hospitalisation and anesthetisation of the donor. Furthermore, the donor will usually experience post-collection pain and discomfort [13]. The extraction of stem cells from the bone marrow also becomes increasingly difficult with aging as the red marrow space changes to a yellow-marrow as it becomes fat-filled with age [23].

Umbilical cord blood stem cells also have the capability to be stored in a bank, allowing for their "off-the-shelf" use, unlike bone marrow [23].

A further advantage of using umbilical cord blood stem cells is the decreased transmission risk of infectious diseases, particularly Epstein-Barr virus and cytomegalovirus as the umbilical cord blood is almost never contaminated by the afore mentioned viruses [20].

Of interest to note is that adipocyte stem cells are another group of stem cells which have been receiving attention lately due to the substantially large amounts that can be harvested from adipose tissue fragments, and their ease of collection via needle biopsy or liposuction aspirates [24] [25]. Furthermore, adipocyte stem cells are considered to be immunoprivileged, meaning graft-versus-host disease can be prevented when using these stem cells, similar to umbilical cord stem cells [26] [27]. 


\subsection{History of Umbilical Stem Cell Transplantation}

The first successful umbilical cord blood stem cell transplant was reported as occurring in 1988 as Gluckman and his colleagues showed that the umbilical cord blood (UCB) contained sufficient HSCs for successful haematological reconstitution [28]. The recipient was a 6-year-old American boy from North Carolina who was treated for Fanconi's anaemia (a genetic disorder) at Hospital St. Louis in Paris, France, using cord blood obtained from his younger sister's birth [29]. This was followed one year later by the first related umbilical cord blood transplant in the United States [30].

Kurtzberg et al. are credited with performing the first successful unrelated umbilical cord blood transplant in the United States in 1994 [31].

\section{Clinical Cases}

In this review, we will be looking into the latest clinical cases making use of stem cells derived from umbilical blood, which are summarised in Table 1.

\subsection{Case Study 1-Chronic Immune Thrombocytopenic Purpura}

Four patients, one male and three females, aged between 26 and 54 years received intravenous infusion of umbilical cord-derived mesenchymal stem cells to treat their condition of chronic refractory immune thrombocytopenia purpura [32].

This condition is an auto-immune acquired disorder characterised by an accelerated destruction of platelets and an inhibited production of platelets [33].

Table 1. A summary of the case studies discussed below.

\begin{tabular}{|c|c|c|c|}
\hline $\begin{array}{c}\text { Case } \\
\text { Number }\end{array}$ & $\begin{array}{l}\text { Sample } \\
\text { Size }\end{array}$ & Outcome & Reference \\
\hline 1 & 4 & $\begin{array}{l}\text { This study showed that hUC-MSC transplantation is a safe } \\
\text { and an effective treatment for ITP, with an annual optimal } \\
\text { period of transplantation. }\end{array}$ & [32] \\
\hline 2 & 2 & $\begin{array}{l}\text { Both paediatric patients, one diagnosed with AML with } \\
\text { MDS-related changes and monosomy } 7 \text { and the other with } \\
\text { MDS with monosomy 7, were treated successfully following } \\
\text { UCB-HSCT transplantation. }\end{array}$ & [34] \\
\hline 3 & 1 & $\begin{array}{l}\text { Following the transplantation of hUC-MSCs, the IPF } \\
\text { patient showed improvements in term of quality of life, } \\
\text { physical performance and respiratory parameters } \\
\text { (lung function, 6MWD and CT fibrosis score). }\end{array}$ & [35] \\
\hline 4 & 34 & $\begin{array}{l}\text { The patients-suffering from moderate to severe } \\
\text { AD-responded positively to hUCB-MSCs transplantation, } \\
\text { showing a dose-dependent therapeutic effect. }\end{array}$ & [36] \\
\hline 5 & 14 & $\begin{array}{l}\text { The test group showed a significantly higher mean root } \\
\text { coverage compared to the control group. }\end{array}$ & [40] \\
\hline 6 & 1 & $\begin{array}{l}8 \text { months post-treatments, the patient had a complete } \\
\text { resolution of all symptoms, showed no complications } \\
\text { related to the HU-MSCs treatment and all medications } \\
\text { were discontinued. }\end{array}$ & [41] \\
\hline
\end{tabular}


The patients were intravenously infused with $10 \mathrm{~mL}$ of human umbilical cord-mesenchymal stem cells (hUC-MSCs) at a density of between $5 \times 10^{6}$ and 1 $\times 10^{7}$ cells $/ \mathrm{ml}$. Responses to the transplant were achieved in all the four patients at the end of the second week after the transplantation. The patients achieved a count of $>50 \times 10^{9}$ platelet/L, with 2 patients achieving a count of more than 90 $\times 10^{9}$ platelet/L [32].

One of the patients sustained response after a single transfusion without the need of any further therapy during the follow up. The other three patients had a relapse within 1 year after their first transfusion, but responded well to the second transfusion [32].

During the entire study period, no clinically significant side effects were reported, with neither ectopic tissue formation nor other illnesses related to the hUC-MSCs treatments being observed [32].

To conclude, although the data obtained is suggestive of incomplete symptom alleviation, and that the underlying mechanisms of such therapy on ITP need further exploration, this study has managed to show that hUC-MSC transplantation is safe and effective for treating ITP, with an annual optimal period of transplantation [32].

\subsection{Case Study 2-Paediatric Patients with MDS/AML Associated with Underlying GATA2 Mutations}

In this case study, Mallhi et al. present two cases of paediatric germ-line GATA2 mutations presenting with myelodysplastic syndrome (MDS) or acute myeloid leukemia (AML) with monosomy 7.

The first patient was a 16-year-old Caucasian male who received a double umbilical cord blood-hematopoietic stem cell transplantation (UCB-HSCT), while the second patient was an 11-year-old Caucasian male who received a single UCB-HSCT. Both patients were successfully treated, with only limited GVHD being seen in both cases, which responded well to immunosuppressive treatment. At the time of the paper's publication, there was no evidence of chronic GVHD [34].

\subsection{Case Study 3-Idiopathic Pulmonary Fibrosis}

A 56-year-old Chinese man was diagnosed with idiopathic pulmonary fibrosis (IPF), a degenerative disease of the lungs characterised by fibrosis. A $10 \mathrm{~mL}$ hUC-MSC intravenous infusion was carried out on the patient with a cell density of $5 \times 106-1 \times 107 / \mathrm{mL}$. The patient was followed for 12 months post-infusion. At the end of the 12-month follow-up, his need for long-term oxygen therapy was reduced substantially, together with improvements in term of quality of life, physical performance and respiratory parameters (lung function, $6 \mathrm{MWD}$ and CT fibrosis score) were all increased from the base line. Throughout the entire study period, no side effects were observed. This study shows the safety and efficacy of transplanting hUC-MSCs to treat IPF and their potential in lung regeneration [35]. 


\subsection{Case Study 4-Atopic Dermatitis}

34 patients, aged between 20 and 60 years, with a moderate to severe case of atopic dermatitis $(\mathrm{AD})$ were enrolled in a two-phase clinical study with a follow up of 1 month and 3 months for the first and second phase, respectively [36].

$\mathrm{AD}$ is a genetic, chronic inflammatory disease of the skin that affects between $1 \%$ to $3 \%$ of adults and $10 \%$ to $20 \%$ of children [37]. Common symptoms of $\mathrm{AD}$ include scratching, pruritus and chronic and/or relapsing eczematous lesions. Social stigma associated with a visible skin disease, the need for frequent visits to a doctor and constant application of messy topical applications further add to the burden of this disease [38].

Patients in the clinical study were randomly assigned to receive hUC-MSC subcutaneously at either a low dose of $2.5 \times 107$ cells or a high dose of $5 \times 107$ cells. An Investigator's Global Assessment (IGA) score, Eczema Area and Severity Index (EASI) score, Severity Scoring for Atopic Dermatitis (SCORAD) score, serum biomarker levels and adverse effect assessments were all used as end points [36].

At week 12, a dose-dependent therapeutic effect was observed, with consistent improvements, both from a visual comparison of the symptoms and from the score ranges, as shown below [36]:

- EASI score range - 0 to 72 ;

- IGA score range - 0 to 5;

- SCORAD score range - 0 to 103.

This study has shown that adults suffering from a moderate to severe AD respond positively to hUCB-MSCs treatment, regardless of the HLA match and with no side effects being experienced.

\subsection{Case Study 5-Gingival Recession Defects}

Gingival recession is the displacement of the gingival margin apically from the cementoenamel junction (CEJ). The resultant root exposure, is not only aesthetically unpleasant, it can also lead to sensitisation and the formation of root caries [39].

In their clinical study, Zanwar et al. compared the efficacy of human umbilical stem cells seeded on polylactic acid (PLA) and polyglycolic acid (PGA) membranes compared to that of PLA/PGA membranes alone in the treatment of multiple gingival recessions.

14 cases of multiple gingival recession-with a Miller's Class I or II classification-were randomly selected and divided into the test group (treated with PLA/PGA membrane seeded with human umbilical stem cells) and the control group (treated PLA/PGA membrane alone). Mean gingival recession at the baseline and 6 months post-operation were recorded [40].

At baseline, the mean gingival recession at 16 and 14 sites in the test and control groups were measured to be at $2.28 \mathrm{~mm}$ and $2.14 \mathrm{~mm}$ respectively. At 6 months post-surgery, the test group showed a $1.57 \mathrm{~mm}$ mean reduction of gin- 
gival recession while the control group showed a mean gingival recession of 1.24 $\mathrm{mm}$; with $66 \%$ and $57 \%$ root coverage, respectively [40].

This study has therefore shown that, patients treated with PLA/PGA membranes containing the human umbilical stem cells showed a significantly higher mean root coverage compared to patients treated with PLA/PGA membranes alone [40].

\subsection{Case Study 6-Primary Systemic Lupus Erythematosus and Secondary Sjogren's Syndrome}

A 26-year-old female patient with primary systemic lupus erythematosus (SLE) and secondary Sjogren's syndrome (SS) was treated with UC-MSCs, 13 years after diagnosis [41].

SLE is an inflammatory, autoimmune disorder forming part of the connective tissue disease (CTD) spectrum. The disease has genetic and environmental components which can influence the incidence of the disease. SLE tends to severely limit the patient's daily activities through pain, fatigue and multiple organ impairment [41].

SS is another type of CTD, characterised by xerostomia, xerophthalmia and parotomegaly in combination with CTD spectrum pathology [41].

The UC-MSCs were delivered to the patient intravenously in four injections of 25 million cells each over a span of 3 weeks, together with $0.25 \mathrm{~mL}$ GcMAF (Gc protein-derived macrophage activating factor) delivered intramuscularly weekly in combination with vitamin D3 5000 IU/600mg calcium supplementation daily [41].

Over the year, prior to this treatment, the patient had cycled through a variety of anti-inflammatory drugs and immunosuppressants with limited efficacy [41].

The treatment was tolerated by the patient with no complications arising. 3 months post-treatment, the patient reported improvements in multi-joint pain and stiffness and began tapering off the medications. 8 months post-treatments, the patient had a complete resolution of all symptoms, showed no complications related to the HU-MSCs treatment and all medications were discontinued [41].

Further studies need to be carried out to elucidate whether the improvement experienced by this patient was through the combined therapy or due to HU-MSC delivery alone.

\section{Umbilical Cord Blood Banking}

Since the first HCTs transplantation from umbilical cord blood (UCB) by Gluckman in 1988, the clinical use of UCB has greatly increased, which led to the development of an entire UCB banking industry [42].

The first effort at establishing an umbilical cord blood bank was undertaken at Indiana University to harvest cells from the siblings of children needing transplants [13]. In 1991, the New York Blood Center established the first public bank for umbilical cord blood through funding provided by the National Heart, Lung, and Blood Institute of the National Institutes of Health (NIH) [43]. 
Nowadays, there are two forms of cord blood banking: public and private banking; the former are non-profit institutions that receive cord blood from voluntary anonymous donors and make it available to transplant centres through the national registries; while the latter store cord blood for the use by the donor's family if the need for autologous transplantation arises in the future, with the blood not being available to the general public [44].

While there are no fees associated with the donation and storage of cord blood by public banks, the costs of private banking range between $\$ 2000$ and $\$ 5000$ for 20 years of storage in the US [44].

In their cost-effectiveness analysis of the private umbilical cord blood banking, Kaimal et al., concluded that it is not cost-effective $\$ 137,426$ per life-year gained on the basis of a 20-year storage fee of $\$ 3620$ [45].

A number of entities, such as the American Academy of Paediatrics (AAP), American College of Obstetricians and Gynecologists (ACOG) and American Society for Blood and Marrow Transplantation (ASBMT) advocate against the use of private cord blood banking for the general population as the probability of developing a disease which will require an umbilical cord transplant is highly unlikely, as long as there is no family history of blood or metabolic disorders. Additionally, if a genetic disease is present, the patient's own cord blood is rendered useless as it would contain the same genetic disease-causing mutation [44] [45] [46].

Although the likelihood of a person needing autologous transplantation is very low, with a probability of less than 1 in 20,000 for the first 20 years of life [47], this does not mean that another member of the community cannot benefit from the UCB, if stored publicly. In fact, private banking represents a lost opportunity for people with certain genetic diseases or cancers from accessing the potentially life-saving stem cells [48]. Unlike bone marrow, the increased storage of UCB in public banks would also mean an increased availability for every ethnic group for tissue matching [46].

For these reasons, entities such as ASBMT recommend private banking only if a sibling of the newborn child has leukaemia, hemoglobinopathy, lymphoma or a bone marrow failure syndrome; all diseases which can be successfully treated with stem cells [49].

Despite all the discussed findings which favour public banking, a study on expecting parents in India found that parents were more steered towards choosing private rather than public banking due to the former's use of advertising and media coverage. Moreover, the majority of the mothers were unaware of UCB and what it entails, highlighting a need for education of the parents by their obstetricians so they can choose the best option for them and their children [50].

Regarding advertising for private banks, the report on the ethics of private umbilical cord banking by the European Commission's Group on Ethics in Science and New Technologies has stated that for private banks to be allowed in the EU member states, correct information should be given to their potential consumers, including the fact that the probability that the stored sample will be 
used to treat one's child is negligible and that future therapeutic possibilities are only of a very hypothetical nature [51].

\section{Conclusion}

From first being considered as a waste product, the umbilical cord has come a long way, where it is now revered for its stem cells content. The umbilical cord stem cells have been shown to be a promising step in the treatment of various illnesses. The increase in usefulness of these stem cells gave rise to the setting up of public and private facilities which could store the umbilical cord blood. As discussed in this paper, public banking facilities are favoured over the private alternative.

\section{References}

[1] Forraz, N. and McGuckin, C.P. (2011) The Umbilical Cord: A Rich and Ethical Stem Cell Source to Advance Regenerative Medicine. Cell Proliferation, 44, 60-69. https://doi.org/10.1111/j.1365-2184.2010.00729.x

[2] Agius, C. and Blundell, R. (2012) The Cutting Edge in Stem Cell Medical Applications. Research Journal of Medical Sciences, 2, 47-50.

[3] Mckenna, D.H., Kadidlo, D.M., Mccullough, J. and Regan, D.M. (2011) Umbilical Cord Blood. In: Roback, J.D., Grossman, B.J., Harris, T. and Hillyer, C.D., Eds., Technical Manual. American Association of Blood Banks, Bethesda, 823-847.

[4] Pace, P. and Blundell, R. (2016) Stem Cells: Daddy or Chips?-An Up-to-Date Review on Ground-Breaking Discoveries in Stem Cell Research with Special Attention to iPSC Applications in Osteoarthritis. Stem Cell Discovery, 6, 39-44. https://doi.org/10.4236/scd.2016.61004

[5] Conconi, M.T., Di Liddo, R., Tommasini, M., Calore, C. and Parnigotti, P.P. (2011) Phenotype and Differentiation Potential of Stromal Populations Obtained from Various Zones of Human Umbilical Cord: An Overview. The Open Tissue Engineering and Regenerative Medicine Journal, 4, 6-20.

[6] Ziaei, M., Zhang, J., Patel, D. and McGhee, C.N.J. (2017) Umbilical Cord Stem Cells in the Treatment of Corneal Disease. Survey of Ophthalmology, 62, 803-815. https://doi.org/10.1016/j.survophthal.2017.02.002

[7] Knudtzon, S. (1974) In Vitro Growth of Granulocytic Colonies from Circulating Cells in Human Cord Blood. Blood, 43, 357-361.

[8] Bieback, K., Kern, S., Kluter, H. and Eichler, H. (2004) Critical Parameters for the Isolation of Mesenchymal Stem Cells from Umbilical Cord Blood. Stem Cells, 22, 625-634. https://doi.org/10.1634/stemcells.22-4-625

[9] Erices, A., Conget, P. and Minguell, J.J. (2000) Mesenchymal Progenitor Cells in Human Umbilical Cord Blood. British Journal of Haematology, 109, 235-242. https://doi.org/10.1046/j.1365-2141.2000.01986.x

[10] Goodwin, H.S., Bicknese, A.R., Chien, S., Bogucki, B.D., Oliver, D.A., Quinn, C.O. and Wall, D.A. (2001) Multi-Lineage Differentiation Activity by Cells Isolated from Umbilical Cord Blood: Expression of Bone, Fat, and Neural Markers. Biology Blood and Marrow Transplantation, 7, 581-588. https://doi.org/10.1053/bbmt.2001.v7.pm11760145

[11] Kögler, G., Sensken, S., Airey, J.A., Trapp, T., Müschen, M., Feldhahn, N., Liedtke, S., Sorg, R.V., Fischer, J., Rosenbaum, C., Greschat, S., Knipper, A., Bender, J., De- 
gistirici, O., Gao, J., Caplan, A.I., Colletti, E.J., Almedia-Porada, G., Müller, H.W., Zanjani, E. and Wernet, P. (2004) A New Human Somatic Stem Cell from Placental Cord Blood with Intrinsic Pluripotent Differentiation Potential. The Journal of EXperimental Medicine, 200, 123-135. https://doi.org/10.1084/jem.20040440

[12] Lee, O.K., Kuo, T.K., Chen, W.M., Lee, K.D., Hsieh, S.L. and Chen, T.H. (2004) Isolation of Multipotent Mesenchymal Stem Cells from Umbilical Cord Blood. Blood, 103, 1669-1675. https://doi.org/10.1182/blood-2003-05-1670

[13] Moise, K.J.Jr. (2005) Umbilical Cord Stem Cells. Obstetrics \& Gynecology, 106, 1393-1407. https://doi.org/10.1097/01.AOG.0000188388.84901.e4

[14] Wexler, S.A., Donaldson, C., Denning-Kendall, P., Rice, C., Bradley, B. and Hows, J.M. (2003) Adult Bone Marrow Is a Rich Source of Human Mesenchymal "Stem" Cells But Umbilical Cord and Mobilized Adult Blood Are Not. British Journal of Haematology, 121, 368-374. https://doi.org/10.1046/j.1365-2141.2003.04284.x

[15] Romanov, Y.A., Svintsitskaya, V.A. and Smirnov, V.N. (2003) Searching for Alternative Sources of Postnatal Human Mesenchymal Stem Cells: Candidate MSC-Like Cells from Umbilical Cord. Stem Cells, 21, 105-110. https://doi.org/10.1634/stemcells.21-1-105

[16] Mareschi, K., Biasin, E., Piacibello, W., Aglietta, M., Madon, E. and Fagioli, F. (2001) Isolation of Human Mesenchymal Stem Cells: Bone Marrow versus Umbilical Cord Blood. Haematologica, 86, 1099-1100.

[17] Cassar, P. and Blundell, R. (2016) The Use of Umbilical Stem Cells. Open Journal of Pathology, 6, 41-56. https://doi.org/10.4236/ojpathology.2016.61007

[18] Rocha, V., Wagner, J.E.Jr., Sobocinski, K.A., Klein, J.P., Zhang, M., Horowitz, M.M. and Gluckman, E. (2000) Graft-versus-Host Disease in Children Who Have Received a Cord-Blood or Bone Marrow Transplant from an HLA-Identical Sibling. The New England Journal of Medicine, 342, 1846-1854. https://doi.org/10.1056/NEJM200006223422501

[19] Rubinstein, P., Carrier, C., Scaradavou, A., Kurtzberg, J., Adamson, J., Migliaccio, A.R., Berkowitz, R.L., Cabbad, M., Dobrila, N.L., Taylor, P.E., Rosenfield, R.E. and Stevens, C.E. (1998) Outcomes among 562 Recipients of Placental-Blood Transplants from Unrelated Donors. The New England Journal of Medicine, 339, 1566-1577. https://doi.org/10.1056/NEJM199811263392201

[20] Gonzalez-Ryan, L., Van Syckle, K., Coyne, K.D. and Glover, N. (2000) Umbilical Cord Blood Banking: Procedural and Ethical Concerns for This New Birth Option. Pediatric Nursing, 26, 105-110.

[21] Percer, B. (2009) Umbilical Cord Blood Banking: Helping Parents Make Informed Choices. Nursing for Women's Health, 13, 216-223. https://doi.org/10.1111/j.1751-486X.2009.01422.x

[22] Rogers, I. and Casper, R.F. (2004) Umbilical Cord Blood Stem Cells. Best Practice \& Research: Clinical Obstetrics \& Gynaecology, 18, 893-908. https://doi.org/10.1016/j.bpobgyn.2004.06.004

[23] Weiss, M.L. and Troyer, D.L. (2006) Stem Cells in the Umbilical Cord. Stem Cell Reviews and Reports, 2, 155-162. https://doi.org/10.1007/s12015-006-0022-y

[24] Jeong, J.H. (2008) Adipose Stem Cells as a Clinically Available and Effective Source of Adult Stem Cell Therapy. International Journal of Stem Cells, 1, 43-48. https://doi.org/10.15283/ijsc.2008.1.1.43

[25] Lindroos, B., Suuronen, R. and Miettinen, S. (2011) The Potential of Adipose Stem Cells in Regenerative Medicine. Stem Cell Reviews and Reviews and Reports, 7, 269-291. https://doi.org/10.1007/s12015-010-9193-7 
[26] Gonzalez-Rey, E., Anderson, P., Gonzalez, M.A., Rico, L., Buscher, D. and Delgado, M. (2009) Human Adult Stem Cells Derived from Adipose Tissue Protect against Experimental Colitis and Sepsis. Gut, 58, 929-939.

https://doi.org/10.1136/gut.2008.168534

[27] Gonzalez-Rey, E., Gonzalez, M.A., Varela, N., O’Valle, F., Hernandez-Cortes, P., Rico, L., Büscher, D. and Delgado, M. (2010) Human Adipose-Derived Mesenchymal Stem Cells Reduce Inflammatory and T Cell Responses and Induce Regulatory T Cells in Vitro in Rheumatoid Arthritis. Annals of the Rheumatic Diseases, 69, 241-248. https://doi.org/10.1136/ard.2008.101881

[28] Watt, S.M. and Contreras, M. (2005) Stem Cell Medicine: Umbilical Cord Blood and Its Stem Cell Potential. Seminars in Fetal and Neonatal Medicine, 10, 209-220. https://doi.org/10.1016/j.siny.2005.02.001

[29] Gluckman, E., Broxmeyer, H.E., Auerbach, A.D., Friendman, H.S., Douglas, G.W., Devergie, A., Esperou, H., Thierry, D., Socie, G., Lehn, P., Cooper, S., English, D., Kurtzberg, J., Bard, J. and Boyse, E.A. (1989) Hematopoietic Reconstitution in a Patient with Fanconi's Anemia by Means of Umbilical-Cord Blood from an HLA-Identical Sibling. The New England Journal of Medicine, 321, 1174-1178. https://doi.org/10.1056/NEJM198910263211707

[30] Smith, F.O. and Thomson, B.G. (2000) Umbilical Cord Blood Collection, Banking, and Transplantation: Current Status and Issues Relevant to Perinatal Caregivers. Birth, 27, 127-135. https://doi.org/10.1046/j.1523-536x.2000.00127.x

[31] Kurtzberg, J., Graham, M., Casey, J., Olson, J., Stevens, C.E. and Rubinstein, P. (1994) The Use of Umbilical Cord Blood in Mismatched Related and Unrelated Hemopoietic Stem Cell Transplantation. Blood Cells, 20, 275-283.

[32] Wang, X., Yin, X., Sun, W., Bai, J., Shen, Y., Ao, Q., Gu, Y. and Liu, Y. (2017) Intravenous Infusion Umbilical Cord-Derived Mesenchymal Stem Cell in Primary Immune Thrombocytopenia: A Two-Year Follow-Up. Experimental and Therapeutic Medicine, 13, 2255-2258. https://doi.org/10.3892/etm.2017.4229

[33] Psaila, B. and Bussel, J.B. (2008) Refractory Immune Thrombocytopenic Purpura: Current Strategies for Investigation and Management. British Journal of Haematology, 143, 16-26. https://doi.org/10.1111/j.1365-2141.2008.07275.x

[34] Mallhi, K., Dix, D.B., Niederhoffer, K.Y., Armstrong, L. and Rozmus, J. (2016) Successful Umbilical Cord Blood Hematopoietic Stem Cell Transplantation in Pediatric Patients with MDS/AML Associated with Underlying GATA2 Mutations: Two Case Reports and Review of Literature. Pediatric Transplantation, 20, 1004-1007. https://doi.org/10.1111/petr.12764

[35] Zhang, C., Yin, X., Zhang, J., Ao, Q., Gu, Y. and Liu, Y. (2017) Clinical Observation of Umbilical Cord Mesenchymal Stem Cell Treatment of Severe Idiopathic Pulmonary Fibrosis: A Case Report. Experimental and Therapeutic Medicine, 13, 1922-1926. https://doi.org/10.3892/etm.2017.4222

[36] Kim, H.S., Lee, J.H., Roh, K.H., Jun, H., Kang, K.S. and Kim, T.Y. (2017) Clinical Trial of Human Umbilical Cord Blood-Derived Stem Cells for the Treatment of Moderate-to-Severe Atopic Dermatitis: Phase I/IIa Studies. Stem Cells, 35, 248-255. https://doi.org/10.1002/stem.2401

[37] Larsen, F.S. and Hanifin, J.M. (2012) Epidemiology of Atopic Dermatitis. Immunology and Allergy Clinics of North America, 22, 1-24. https://doi.org/10.1016/S0889-8561(03)00066-3

[38] Hoare, C., Li Wan Po, A. and Williams, H. (2000) Systematic Review of Treatments for Atopic Eczema. Health Technology Assessment, 4, 1-191. 
[39] Kassab, M.M. and Cohen, R.E. (2003) The Etiology and Prevalence of Gingival Recession. The Journal of the American Dental Association, 134, 220-225. https://doi.org/10.14219/jada.archive.2003.0137

[40] Zanwar, K., Kumar Ganji, K. and Bhongade, M.L. (2017) Efficacy of Human Umbilical Stem Cells Cultured on Polylactic/Polyglycolic Acid Membrane in the Treatment of Multiple Gingival Recession Defects: A Randomized Controlled Clinical Study. Journal of Dentistry (Shiraz), 18, 95-103.

[41] Phillips, C.D., Wongsaisri, P., Htut, T. and Grossman, T. (2017) Purified Umbilical Cord Derived Mesenchymal Stem Cell Treatment in a Case of Systemic Lupus Erythematosus. Clinical and Translational Medicine, 6, 31. https://doi.org/10.1186/s40169-017-0161-6

[42] Rao, M., Ahrlund-Richter, L. and Kaufman, D.S. (2012) Concise Review: Cord Blood Banking, Transplantation and Induced Pluripotent Stem Cell: Success and Opportunities. Stem Cells, 30, 55-60. https://doi.org/10.1002/stem.770

[43] Rubinstein, P., Rosenfield, R.E., Adamson, J.W. and Stevens, C.E. (1993) Stored Placental Blood for Unrelated Bone Marrow Reconstitution. Blood, 81, 1679-1690.

[44] Martin, A. and Badell, M. (2014) Umbilical Cord Blood Banking. Topics in Obstetrics \& Gynecology, 34, 1-5. https://doi.org/10.1097/01.PGO.0000452207.26653.05

[45] Kaimal, A.J., Smith, C.C., Laros, R.K.J., Caughey, A.B. and Cheng, Y.W. (2009) Cost-Effectiveness of Private Umbilical Cord Blood Banking. Obstetrics \& Gynecology, 114, 848-855. https://doi.org/10.1097/AOG.0b013e3181b8fc0d

[46] Fisk, N.M., Roberts, I.A., Markwald, R., Mironov, V. (2005) Can Routine Commercial Cord Blood Banking Be Scientifically and Ethically Justified? PLOS Medicine, 2, e44. https://doi.org/10.1371/journal.pmed.0020044

[47] Annas, G.J. (1999) Waste and Longing-The Legal Status of Placental-Blood Banking. The New England Journal of Medicine, 340, 1521-1524. https://doi.org/10.1056/NEJM199905133401923

[48] Herlihy, M.M. and Delpapa, E.H. (2013) Obstetricians and Their Role in Cord Blood Banking: Promoting a Public Model. Obstetrics \& Gynecology, 121, 851-855. https://doi.org/10.1097/AOG.0b013e31828882aa

[49] Ballen, K., Barker, J., Stewart, S., Greene, M. and Lane, T. (2008) ASBMT Committee REPORT: Collection and Preservation of Cord Blood for Personal Use. Biology of Blood and Marrow Transplantation, 14, 356-363. https://doi.org/10.1016/j.bbmt.2007.11.005

[50] Pandey, D., Kaur, S. and Kamath, A. (2016) Banking Umbilical Cord Blood (UCB) Stem Cells: Awareness, Attitude and Expectations of Potential Donors from One of the Largest Potential Repository (India). PLoS ONE, 11, e0155782. https://doi.org/10.1371/journal.pone.0155782

[51] Sullivan, M.J. (2008) Banking on Cord Blood Stem Cells. Nature Reviews Cancer, 8, 554-563. https://doi.org/10.1038/nrc2418-c3 